\title{
Prevention of Healthcare Associated Infections in the Tuberculosis Health Center

\author{
${ }^{1}$ Ilya V. Petrov, ${ }^{2}$ Marina O. Novikova, ${ }^{3}$ Lyudmila V. Petrova, ${ }^{4}$ Artur A. Almukhametov, ${ }^{5}$ Firuza S. \\ Petrova \\ ${ }^{1,4}$ Kazan Federal University, University Hospital "Kazan"; Kazan State Medical Republican TB Health, \\ ${ }^{2,3}$ Center of the Ministry of Health of the Republic of Mari El University of Tatarstan, ${ }^{5}$ Regional office of \\ Rospotrebnadzor in the Republic of Tatarstan
}

Received: 15th December 2017, Accepted: 20th December 2017, Published: 31st December 2017

\begin{abstract}
Prevention of healthcare-associated infections associated (HAI) is an important part of the activities of a medical organization (MO), focused on the quality and safety of medical services. Epidemiological safety of the profile infectious MO requires strict adherence to the sanitary and antiepidemic regime. An example of such a MO is the State Budgetary Institution of the Republic of Mari El, Republican Tuberculosis Health Center (RATHC). The analysis of sanitary and epidemiological well-being on the example of the RATHC used the methods of retrospective and operative epidemiological analysis of cases among staff and patients, as well as data of microbiological monitoring. Based on the results of the analysis for the period of 2002-2016, there were 7 cases of HAI among the staff, which are tuberculosis processes, 116 cases of HAI were found among the patients, not associated with tuberculosis. According to the microbiological monitoring (MBM) of the RATHC, there has been a decrease in studies aimed at detecting coliform bacteria (CB) (1.5 times), $S$. aureus from the surfaces of the RATHC objects (1.5 times), pathogenic flora (1.5 times), and working solutions of disinfectants for the activity of the active substance (ASA) (1.2 times). At the same time, there has been an increase in research aimed at determining microbial contamination of air (a total microbial number by 8.6 times, $S$. aureus by 8.6 times), a degree of sterility of medical products (MP) by 2.4 times and the pre-sterilization quality control of medical products (MPPSQC) by 1.5 times. Epidemiologically significant structural subdivisions (children's department, surgical and therapeutic departments, clinical diagnostic and bacteriological laboratories) have been established. The obtained results indicate the need for staff motivation to comply with the established instructions and protocols to ensure the sanitary and epidemiological well-being of the medical organization.
\end{abstract}

Keywords: Healthcare-Associated Infections; Tuberculosis; Microbiological Monitoring; Sanitary and Epidemiological Well-Being.

\section{Introduction}

HAI occupy an actual place in the modern healthcare system in terms of hygiene and epidemiology, the quality management system in medical organizations, since epidemiological safety is one of the tools for targeting to the consumer of medical services with the involvement of medical personnel to achieve this goal $[1,2,3,4,5,6]$.

The Russian Federation in 2011 enacted "The National Concept for the Prevention of HealthcareAssociated Infections", approved by the Chief State Sanitary Doctor of the Russian Federation on November 6, 2011, which fully identifies the demographic, economic, medical aspects of this issue and ways to solve this problem. Economic analysis according to the national concept is one of the criteria for assessing the prevention of HAI $[7,8,9,10]$.

Prevention of HAI in medical organizations is the main activity of the departmental epidemiological service, which requires close monitoring in surgical hospitals, perinatal centers, and in specialized health centers. A tuberculosis health center is an example of a medical organization, where the risk of developing nosocomial tuberculosis is great both among patients and its employees due to the peculiarities of the transmission mechanism of this pathogen [11].

Despite the fact that in the Russian Federation there is a tendency to reduce the incidence of tuberculosis, this nosology remains one of the most socially significant infectious diseases, including in the structure of occupational diseases, which indicates the existing risk of tuberculosis development as HAI among medical staff. In 2016, in the territory of the Russian Federation, the dominant in the structure of occupational diseases and poisonings (with the biological factor of the production environment as the key factor in the pathogenesis of the development of occupational disease) among medical personnel and other employees of organizations classified as "Healthcare" in accordance with the all-Russian classifier of economic activities, are respiratory tuberculosis - 85.5\% (2015 - 88.7\%), and tuberculosis of other organs - 8.6\% (2015-4.1\%). The investigations of occupational diseases have revealed the following main factors and conditions for the emergence of pathologies: contact with the 
infectious agent during labor activity $-42.7 \%$ of cases, imperfect workplace arrangement $-13.1 \%$, improper use of personal protective equipment (PPE) - $12.6 \%$, and imperfect technological processes $-8.0 \%$ [12].

In 2016, the Republic of Mari El (RME) had no cases of nosocomial tuberculosis registered in the structure of the HAI of the RATHC, which is explained by strict observance of the sanitary legislation in the field of epidemiological safety, and the understanding by the medical personnel of the internal instructions for compliance with the sanitary and anti-epidemic regime. This study analyzes the results of implementing risk management from the standpoint of ensuring sanitary and epidemiological well-being in the conditions of the RATHC $[13,14$, $15]$.

Table 1.Structure of the TB Health Center of the Republic of Mari EI

\begin{tabular}{|c|c|c|}
\hline $\begin{array}{c}\text { Number of structural } \\
\text { departments }\end{array}$ & Location & Name of the structural department \\
\hline 1. & \multirow{9}{*}{ Yoshkar-Ola } & Administrative and economic part \\
\hline 2. & & Health center department \\
\hline 3. & & $\begin{array}{l}\text { Department of extra pulmonary forms of } \\
\text { tuberculosis ( } 40 \text { round - the - clock beds, } 5 \text { - day } \\
\text { hospital) }\end{array}$ \\
\hline 4. & & $\begin{array}{l}\text { Pulmonary and surgical department ( } 43 \text { round-the- } \\
\text { clock beds, 2-day hospital), incl. Chambers where } \\
\text { multidrug-resistant patients are located) }\end{array}$ \\
\hline 5. & & $\begin{array}{l}\text { Children's department ( } 35 \text { round-the-clock beds, 5- } \\
\text { day hospital) }\end{array}$ \\
\hline 6. & & Bacteriological laboratory \\
\hline 7. & & $\begin{array}{l}\text { Clinical and diagnostic laboratory (part of the health } \\
\text { center department) }\end{array}$ \\
\hline 8. & & $\begin{array}{l}\text { X-ray department (part of the health center } \\
\text { department) }\end{array}$ \\
\hline 9. & & Catering unit \\
\hline 10. & \multirow{3}{*}{$\begin{array}{l}\text { A residential area of Kuyar, } \\
\text { Medvedevsky District }\end{array}$} & $\begin{array}{l}\text { Therapeutic department №1 (50 round-the-clock } \\
\text { beds) }\end{array}$ \\
\hline 11. & & $\begin{array}{l}\text { Therapeutic department №2 ( } 30 \text { round-the-clock } \\
\text { beds), where there are patients with multiple drug } \\
\text { resistance) }\end{array}$ \\
\hline 12. & & Catering unit \\
\hline 13. & \multirow{2}{*}{$\begin{array}{l}\text { Kransnogorsk village, } \\
\text { Zvenigovo district }\end{array}$} & Children's sanatorium (50 round-the-clock beds \\
\hline 14. & & Catering unit \\
\hline
\end{tabular}

The epidemiologically significant departments of the RATHC are all the departments equipped with beds, rooms for medical procedures and examinations conducted by specialists, and laboratories. Less epidemiologically significant structural department

\section{Materials and Methods}

The HAI log (infectious diseases log No.60), production control MBM log of the RATHC for the period of 2002-2016 were analyzed. Methods of retrospective and operative epidemiological analysis, data of the form of the federal state statistical observation No. 30 "Information on the medical organization" were used.

\section{Results and Discussion}

The RATHC is located in Yoshkar-Ola, the village of Kuyar, Medvedevsky district (about $9 \mathrm{~km}$ from the city of Yoshkar-Ola) and in the village of Krasnogorsky, Zvenigovsky district (about $60 \mathrm{~km}$ from the city of Yoshkar-Ola). The structure of the MO is presented in Table. 1. is the catering unit, since it is used for cooking only, and the patients are fed directly in the departments. No epidemiological danger is detected in the administrative and economic divisions. 
Table 2.Cases of Healthcare Associated Infections among Staff TB Health Center of the Republic of Mari El

\begin{tabular}{|c|c|c|c|c|}
\hline Year & Sex / Age / Position & Diagnosis & Source of Infection & $\begin{array}{l}\text { Department of the } \\
\text { health center, where } \\
\text { the case of the HAI } \\
\text { was registered }\end{array}$ \\
\hline 2002 & $\begin{array}{l}\text { Female, } \\
27 \text { years, } \\
\text { nurse }\end{array}$ & $\begin{array}{l}\text { Focal tuberculosis S2 of } \\
\text { the right lung in the phase } \\
\text { of infiltration, Bacillus } \\
\text { Kocha (BK) } \\
\text { Newly discovered case }\end{array}$ & $\begin{array}{l}\text { Case of nosocomial } \\
\text { infection }\end{array}$ & $\begin{array}{l}\text { Therapeutic } \\
\text { department }\end{array}$ \\
\hline 2003 & $\begin{array}{c}\text { Female, 22, Paramedic } \\
\text { assistant }\end{array}$ & $\begin{array}{l}\text { Focal tuberculosis } \mathrm{S} 2 \text { of } \\
\text { the right lung in the phase } \\
\text { of infiltration, BK- Newly } \\
\text { discovered case }\end{array}$ & $\begin{array}{l}\text { Case of nosocomial } \\
\text { infection }\end{array}$ & $\begin{array}{c}\text { Clinical and diagnostic } \\
\text { laboratory }\end{array}$ \\
\hline \multirow[b]{2}{*}{2004} & $\begin{array}{c}\text { Man, } \\
60 \text { years, } \\
\text { Radiologist } \\
\end{array}$ & $\begin{array}{c}\text { Disseminated pulmonary } \\
\text { tuberculosis with decay, } \\
\text { BC + Relapse }\end{array}$ & $\begin{array}{l}\text { Case of nosocomial } \\
\text { infection }\end{array}$ & $\begin{array}{l}\text { Health center } \\
\text { department }\end{array}$ \\
\hline & $\begin{array}{l}\text { Female, } \\
26 \text { years, } \\
\text { Junior nurse }\end{array}$ & $\begin{array}{c}\text { Infiltrative tuberculosis } \\
\text { with decay and seeding, } \\
\text { BK + Newly discovered } \\
\text { case }\end{array}$ & $\begin{array}{l}\text { Case of nosocomial } \\
\text { infection }\end{array}$ & $\begin{array}{l}\text { Pulmonary and } \\
\text { surgical department }\end{array}$ \\
\hline 2006 & Female, 45 years, Junior nurse & $\begin{array}{l}\text { Focal tuberculosis of the } \\
\text { upper lobe of } S 2 \text { of the left } \\
\text { lung in the phase of decay } \\
\text { Newly discovered case }\end{array}$ & $\begin{array}{l}\text { Case of nosocomial } \\
\text { infection }\end{array}$ & $\begin{array}{c}\text { Pulmonary and } \\
\text { surgical department }\end{array}$ \\
\hline 2009 & $\begin{array}{l}\text { Female, } 36 \text { years, } \\
\text { Phthisiatrician }\end{array}$ & $\begin{array}{l}\text { Focal tuberculosis of the } \\
\text { upper lobe } \mathrm{S} 2 \text { of the right } \\
\text { lung in the infiltration } \\
\text { phase, BK- Newly } \\
\text { discovered case }\end{array}$ & $\begin{array}{l}\text { Case of nosocomial } \\
\text { infection }\end{array}$ & Children's department \\
\hline 2012 & Female, 27 years, Junior nurse & $\begin{array}{l}\text { Multiple tuberculosis, BK } \\
+ \text { Newly discovered case }\end{array}$ & $\begin{array}{l}\text { Case of nosocomial } \\
\text { infection }\end{array}$ & $\begin{array}{l}\text { Pulmonary and } \\
\text { surgical department }\end{array}$ \\
\hline 2013 & & Not registered & & \\
\hline 2014 & & Not registered & & \\
\hline 2015 & & Not registered & & \\
\hline 2016 & & Not registered & & \\
\hline
\end{tabular}

For the period of 2002-2016, among the staff of the RATHC, 7 cases of HAI were registered. It is worth noting that from 2013 to 2016 no cases of HAI were registered in this cohort. Analysis of the cases of HAI among the staff of the RATHC indicates that the pulmonary-surgical department is leading among the structural departments in the development of nosocomial infections ( $43 \%$ or 3 cases). The therapeutic, health center, children departments, as well as the clinical diagnostic laboratory had one case each registered (14.25\%, respectively). All cases of occupational infection are classified as tuberculosis (ICD-10 A15-A19). Causes of HAI among the staff are the established cases of noncompliance with sanitary and anti-epidemic instructions in the RATHC (Table 2).

In the professional structure of the HAI the share of junior medical staff ( $43 \%$ or 3 cases) prevails, while doctors and nursing staff account for $28.5 \%$ or 2 cases respectively (Fig.1).

Figure 1.The Professional Structure of Healthcare Associated Infections for 2002-2016 Years among Staff of the TB Health Center of the Republic of Mari El

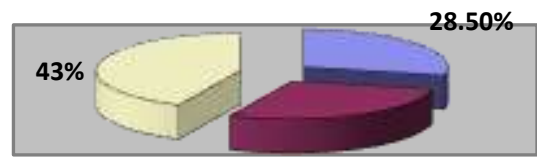


The results of the MBM data of the RATHC are presented in Table 3. Compliance/noncompliance of the results obtained is regulated by sanitary rules and norms SanPiN 2.1.2630-10 "Sanitary and epidemiological requirements for organizations engaged in medical activities", sanitary rules SP 1.1.1058-01 "Organization and implementation of industrial control over compliance with sanitary regulations and implementation of sanitary and anti-epidemic (prophylactic) measures", methodical guidelines MUK 4.2.2942-11 "Methods of sanitary-bacteriological studies of environmental objects, air and sterility control in medical organizations".

Table 3.Results of Microbiological Studies

\begin{tabular}{|c|c|c|c|}
\hline \multicolumn{2}{|r|}{ Name of Instrumental and Laboratory Study } & \multirow{2}{*}{$\begin{array}{c}2002 \\
688 \\
\end{array}$} & \multirow{2}{*}{$\begin{array}{c}2016 \\
463 \\
\end{array}$} \\
\hline 1. & Research on CGB & & \\
\hline & Including inappropriate & 4 & 0 \\
\hline \multirow[t]{2}{*}{2.} & Studies on S. aureus & 688 & 463 \\
\hline & Including inappropriate & 0 & 0 \\
\hline \multirow[t]{2}{*}{3.} & Research on pathogenic flora & 688 & 463 \\
\hline & Including inappropriate & 0 & 0 \\
\hline \multirow[t]{2}{*}{4.} & Air to the total microbial number & 16 & 138 \\
\hline & Including inappropriate & 0 & 0 \\
\hline \multirow[t]{2}{*}{5.} & Air on S. aureus & 16 & 138 \\
\hline & Including inappropriate & 0 & 0 \\
\hline \multirow[t]{2}{*}{6.} & Sterility of medical devices & 340 & 808 \\
\hline & Including inappropriate & 0 & 1 \\
\hline \multirow[t]{2}{*}{7.} & $\begin{array}{l}\text { Working solutions of disinfectants for the activity of the } \\
\text { active substance }\end{array}$ & 344 & 299 \\
\hline & Including inappropriate & 0 & 0 \\
\hline \multirow[t]{2}{*}{8.} & $\begin{array}{l}\text { Quality control of pre-sterilization treatment of medical } \\
\text { devices }\end{array}$ & 11348 & 16463 \\
\hline & Including inappropriate & 0 & 0 \\
\hline
\end{tabular}

For the period of 2002-2016, there was a decrease in the total number of studies of the objects of the RATHC within the framework of production control (due to the cancellation of the order of the Ministry of Health of the USSR No. 720 of July 31, 1978). There has been a decrease in studies aimed at detecting coliform bacteria (1.5 times), S. aureus from the surfaces of the RATHC objects (1.5 times), pathogenic flora (1.5 times), and working solutions of disinfectants for the activity of the active substance (ASA) (1.2 times). At the same time, there has been an increase in research aimed at determining microbial contamination of air (total microbial number by 8.6 times, $S$. aureus by 8.6 times), a degree of sterility of medical products by 2.4 times and the pre-sterilization quality control of medical products (MPPSQC) by 1.5 times.

As a result of the MBM analysis, there is a decrease in inadequate indicators among the results of the $\mathrm{CB}$ tests (2002 - 4 inadequate results, 2016 - 0 similar indicators, respectively). During the period studied, there was a slight increase in inadequate indicators among the sterility tests $(2002-0,2016-1)$.

Table 4.Cases of Healthcare Associated Infections among patients TB health center of the Republic of Mari El

\begin{tabular}{|c|c|c|c|c|}
\hline Year & Diagnosis & Sex & Source of infection & Department \\
\hline 2002 & 7 cases of Chicken Pox & 5 boys, 2 girls & $\begin{array}{l}1 \text { case from outside } \\
6 \text { case - by contact }\end{array}$ & $\begin{array}{l}\text { Children's } \\
\text { department }\end{array}$ \\
\hline 2003 & 2 cases of ARVI & 2 girls & Source not detected & $\begin{array}{l}\text { Children's } \\
\text { department }\end{array}$ \\
\hline 2004 & 6 cases of ARVI & 2 boys, 4 girls & Source not detected & $\begin{array}{l}\text { Children's } \\
\text { department }\end{array}$ \\
\hline 2006 & 2 cases of ARVI & 2 girls & Source not detected & $\begin{array}{l}\text { Children's } \\
\text { department }\end{array}$ \\
\hline 2007 & 7 cases of Chicken Pox & 3 boys, 4 girls & $\begin{array}{l}1 \text { case from outside } \\
6 \text { cases - by contact }\end{array}$ & $\begin{array}{l}\text { Children's } \\
\text { department }\end{array}$ \\
\hline
\end{tabular}




\begin{tabular}{|c|c|c|c|c|}
\hline 2008 & 6 cases of ARVI & 3 boys, 3 girls & Source not detected & $\begin{array}{l}\text { Children's } \\
\text { department }\end{array}$ \\
\hline \multirow[b]{2}{*}{2009} & 22 cases of ARVI & 10 boys, 12 girls & Source not detected & \multirow{2}{*}{$\begin{array}{l}\text { Children's } \\
\text { department }\end{array}$} \\
\hline & 22 cases of chicken pox & 12 boys, 10 girls & $\begin{array}{l}1 \text { case from outside } \\
21 \text { cases - by contact }\end{array}$ & \\
\hline \multirow{2}{*}{2010} & 4 cases of ARVI & 3 boys, 1 girl & Source not detected & $\begin{array}{c}\text { Children's } \\
\text { department }\end{array}$ \\
\hline & 1 case of lacunar angina & 1 male & Source not detected & $\begin{array}{c}\text { Pulmonary and } \\
\text { surgical department }\end{array}$ \\
\hline \multirow{3}{*}{2011} & 8 cases of chicken pox & 4 boys, 4 girls & $\begin{array}{l}1 \text { case from outside } \\
7 \text { cases - by contact }\end{array}$ & $\begin{array}{l}\text { Children's } \\
\text { department }\end{array}$ \\
\hline & 1 case of chicken pox & 1 male & By contact & $\begin{array}{l}\text { Department of } \\
\text { extrapulmonary } \\
\text { forms of } \\
\text { tuberculosis }\end{array}$ \\
\hline & 2 cases of ARVI & 1 boy, 1 girl & Source not detected & $\begin{array}{c}\text { Children's } \\
\text { department }\end{array}$ \\
\hline \multirow[t]{2}{*}{2012} & 1 case of chicken pox & 1 male & By contact & $\begin{array}{l}\text { Department of } \\
\text { extrapulmonary } \\
\text { forms of } \\
\text { tuberculosis }\end{array}$ \\
\hline & 1 case of ARVI & 1 girl & Source not detected & $\begin{array}{c}\text { Children's } \\
\text { department }\end{array}$ \\
\hline \multirow{2}{*}{2013} & 1 case of ARVI & 1 girl & Source not detected & $\begin{array}{l}\text { Children's } \\
\text { department }\end{array}$ \\
\hline & $\begin{array}{l}2 \text { cases of ARVI with } \\
\text { complications }\end{array}$ & 2 boys & Source not detected & $\begin{array}{l}\text { Children's } \\
\text { department }\end{array}$ \\
\hline 2014 & Not registered & & & \\
\hline 2015 & 1 case of ARVI & 1 girl & Source not detected & $\begin{array}{l}\text { Children's } \\
\text { department }\end{array}$ \\
\hline \multirow{2}{*}{2016} & 5 cases of chicken pox & 1 boy, 4 girls & $\begin{array}{l}1 \text { case }- \text { of outside } \\
4 \text { cases }- \text { by contact }\end{array}$ & \multirow{2}{*}{$\begin{array}{l}\text { Children's } \\
\text { department }\end{array}$} \\
\hline & $\begin{array}{l}1 \text { case of ARVI with } \\
\text { complications }\end{array}$ & 1 girl & Source not detected & \\
\hline
\end{tabular}

During 2002-2016, 116 cases of nosocomial infections were detected among patients. The dominant in the structure of HAI are ARVI $(52.6 \%$ or 61 cases), a smaller proportion is occupied by cases of chicken pox (44\% or 51 cases) and acute respiratory viral infection with complications $(2.6 \%$ or 3 cases). Lacunar angina was diagnosed once $(0.8 \%)$ in 2010 . Among the structural subdivisions, the largest number of HAI cases was diagnosed in the children's department ( $97.4 \%$ or 113 cases), which is explained by the lack of mechanisms of child immdepartmenty, the large crowding of children and the absence of strong habits of personal hygiene [16].

\section{Conclusion}

There has been a decrease in the incidence of HAI among the RATHC employees and patients, which indicates compliance with the sanitary and antiepidemic regime in the MO, and also reflects the quality of medical care provided to the population.
The MBM serves as a tool that allows for timely response to various violations of internal instructions and protocols for ensuring sanitary and epidemiological well-being by medical personnel. At the same time, despite the fact that the number of studies has decreased, this has not affected the quality of compliance with the sanitary and antiepidemic regime, as evidenced by the absence of nosocomial cases of tuberculosis since 2012, as well as a decrease in the number of other HAI in the organization.

\section{Acknowledgements}

The authors are grateful to the Kazan Federal University for their assistance in this study.

\section{References}

1. Evaluating the clinical and economic burden of healthcare-associated infections during hospitalization for surgery in France. / L. Lamarsalle, B. Hunt, M. Schauf and el. // 
EpidemiolInfect. - 2013. - № 141 (12). - P. 2473 2482.

2. Healthcare-associated Infections (HAI) Progress report. Available at: http:// www.cdc.gov/hai/progress-report/index.html 3. Masud F. Preventing healthcare-associated infections in cardiac surgical patients as a hallmark of excellence. / F. Masud, D. Vykoukal // Methodist Debakey Cardiovasc - J. 2011. - № 7 (2). - P. 4850 .

4. Moon K. Infection Control Principles for the Management of Construction,

Renovation, Repairs and Maintenance within Health Care Facilities. A Manual for Reducing the Risk of Health Care Associated Infection by Dust and Water Borne Microorganisms/ 2nd Edition. Loddon Mallee Region Infection Control Resource Centre. 2005. 40 p.

5. Australian Guidelines for the Prevention and Control of Infection in Healthcare. Australian Government, 2010. 266p. Available at: http://www.nhmrc.gov.au/_files_nhmrc/publication s/attachments/cd33_complete.pdf

6. Guide: Monitoring program for unannounced inspections undertaken

against the National Standards for the Prevention and Control of Healthcare

Associated Infection/ Health Information and Quality Authority. Dublin.

2015. 63 p.

7. The national concept of the prevention of healthcare-associated infections, and information material on its provisions / Pokrovskii V.I. [et al.]. N. Novgorod: Remedium Privolzhie, 2012. - p. 84. 8. Ivanova N.Iu. Comprehensive epidemiological and economic analysis of healthcare-associated infections of newborns and puerperas in the period of epidemiological trouble in the maternity hospital / N.Iu. Ivanova, O.V. Kovalishina // Modern problems of science and education. - 2013. - No. 4. P. 113.

9. New AHRQ Data Show Healthcare-associated Infections Greatly Increase the Length and Cost of Hospital Stays: Patient Safety and Health IT Newsletter, Issue \#60. September 2010. Agency for Healthcare Research and Quality, Rockville, MD. URL:

http://www.ahrq.gov/news/newsletters/patientsafety/60.html (accessed date: 17.06.2013).

10. Preventing Healthcare-Associated Infections: Initiating Promising Solutions and Expanding Proven Ones: By Carolyn M. Clancy, M.D., Director, Agency for Healthcare Research and Quality. April 2010. Agency for Healthcare Research and Quality, Rockville, MD. - URL: http://www.ahrq.gov/news/newsroom/commentarie s/preventing-healthcare-associatedinfections. html (accessed date: 17.06.2013).
11. Nosocomial tuberculosis infection - justification of the concept of epidemiological diagnostics / E.B. Miasnikova, N.R. Sagieva, V.Iu. Zhuravlev, P.K. Iablonskii // Medical alliance. - 2014. - No. 1. - P. 618.

12. On the state of sanitary and epidemiological welfare of the population in the Russian Federation in 2016: State report. - M: Federal Service for Supervision of Consumer Rights Protection and Human Welfare, 2017. - p. 220.

13. SanPiN 2.1.3.2630-10. Sanitary and epidemiological requirements for organizations engaged in medical activities. Approved by the resolution of the Chief State Sanitary Doctor of the Russian Federation No. 58 of May 18, 2010. M.; 2010 .

14. Prevention of tuberculosis. Sanitary and epidemiological guidelines SP 3.1.2.3114-13 Deputy Chief Physician. -2014. - No. 8. - Pp. 110125.

15. Chikina O.G. Modern approach to quality management of medical care in the epidemiological safety system of medical organizations / O.G. Chikina, A.S. Blagonravova, E.B. Sultanova // Medical almanac. - 2015. No. 5 (40). - Pp. 35-39. 16. Valiulina S.A. The state of children's health in terms of the quality of life / S.A. Valiulina, I.V. Viniarskaia // Questions of modern pediatrics. 2006. - V.5. - Pp. 18-21. 